Abuyazid Bustomi dan Barhamudin, Konsolidasi Sebagai Alternatif Penyediaan Tanah Untuk Pembangunan Sarana dan Fasilitas Umum, Halaman 46-63

\title{
KONSOLIDASI SEBAGAI ALTERNATIF PENYEDIAAN TANAH UNTUK PEMBANGUNAN SARANA DAN FASILITAS UMUM
}

\author{
Abuyazid Bustomi ${ }^{1}$ dan Barhamudin ${ }^{2}$ \\ ${ }^{1}$ Fakultas Hukum Universitas Palembang \\ E-mail: Abuyazid.bustomi13.ab@gmail.com \\ ${ }^{2}$ Fakultas Hukum Universitas Palembang \\ E-mail: bsuryaigama@yahoo.com
}

\begin{abstract}
The politics of consolidation is done to help the community in their efforts to make the area orderly and orderly, and the involvement of the government is very dominant. Land consolidation in Indonesia is aimed at slums or border areas or residential areas. The initiative to carry out land consolidation comes from the government, but it can also come from private companies. This research method is normative / literature, which is to get data from literature, books and legislation. The results of the study that the consolidation of land carried out to strengthen the value and function of the soil as a result of the arrangement of the shape, area, and location so that it becomes orderly and orderly that supports land use effectively and efficiently according to its potential. The obstacles if there are people who object to the consolidation of land for the development of public interests and public facilities. Obstacles from landowners in land consolidation, namely the difficulty of obtaining approval or agreement from landowners in land consolidation because the landowners' approval determines the issuance of a Regent / Mayor's decree on determining the location of land consolidation. The obstacle of the regional government in land consolidation is limited authority because the limitation of land rights is not the authority of the Regent / Mayor.
\end{abstract}

Keywords: Land Rights; Consolidation

\begin{abstract}
Abstrak
Politik dari konsolidasi dilakukan untuk membantu masyarakat dalam usahanya untuk menjadikan daerah itu tertib dan teratur, dan keterlibatan pemerintah sangat dominan. Konsolidasi tanah di Indonesia ditujukan kepada daerah-daerah kumuh ataupun kepada daerah-daerah perbatasan ataupun daerah pemukiman. Inisiatif untuk melaksanakan konsolidasi tanah berasal dari pemerintah, namun bisa juga dari perusahaan swasta. Metode penelitian ini adalah normatif/kepustakaan, yaitu untuk mendapatkan data-data dari literaturliteratur, buku-buku dan peraturan perundang-undangan. Hasil penelitian bahwa konsolidasi tanah dilakukan untuk penguatan nilai dan fungsi tanah sebagai hasil penataan bentuk, luas, dan letak sehingga menjadi tertib dan teratur yang mendukung pemanfaatan lahan secara efektif dan efisien sesuai potensinya. Adapun hambatannya apabila ada masyarakat yang keberatan dengan konsolidasi tanah untuk pembangunan kepentingan umum dan fasilitas umum. Hambatan dari pemilik tanah dalam konsolidasi tanah, yakni sulitnya mendapatkan persetujuan atau kesepakatan dari pemilik tanah dalam konsolidasi tanah karena persetujuan pemilik tanah menentukan dikeluarkannya keputusan Bupati/Walikota tentang penetapan lokasi konsolidasi tanah. Hambatan dari pemerintah daerah dalam konsolidasi tanah adalah wewenang yang terbatas karena pembatasan hak atas tanah bukan wewenang Bupati/Walikota. Kata Kunci: Hak Atas Tanah; Konsolidasi
\end{abstract}

\section{PENDAHULUAN}

Sebagian masyarakat masih beranggapan bahwa hak atas tanah adalah hak mutlak, artinya hak yang tidak dapat diganggu gugat terhadap tanah padahal hak atas tanah di 
Abuyazid Bustomi dan Barhamudin, Konsolidasi Sebagai Alternatif Penyediaan Tanah Untuk Pembangunan Sarana dan Fasilitas Umum, Halaman 46-63

dalamnya mengandung fungsi sosial, artinya tanah bisa dimanfaatkan oleh siapa pun asalkan prosedur hukum telah ditempuh, terlebih apabila calon pengguna tanah adalah negara dan digunakan untuk kepentingan umum. Sebetulnya berdasarkan hak yang dimiliki oleh negara, demi kepentingan umum negara berhak untuk melakukan pemaksaan seseorang atau lembaga hukum untuk melapaskan hak atas tanahnya. Namun hak negara ini tidak boleh meninggalakan prinsip kepemilikan individu. ${ }^{1}$

Persoalan pembebasan tanah untuk kepentingan umum pada umumnya timbul karena tidak terdapat persesuaian harga, yang sering memperuncing masalah dengan turut campur tangannya pihak-pihak tertentu yang ingin mendapatkan keuntungan pribadi dengan memprovokasi masyarakat/warga pemilik tanah untuk meminta harga yang sangat tinggi/tidak wajar, yang mengakibatkan musyawarah tidak mencapai mufakat, dan pembangunan terhambat karena penyelesaian menjadi berlarut-larut dan berkepanjangan. Berbagai sengketa kepemilikan tanah yang terjadi tidak

\footnotetext{
${ }^{1}$ Mukadir, "Model Pembebasan Tanah Untuk Kepentingan Umum, ” Jurnal Media Jaya No. 006 Th XXVIII Juli (2004): 48.
}

lain karena pihak yang bersengketa merasa bahwa alas hak yang dimiliki dianggap paling benar atau yang satu didasarkan atas surat yang dimiliki sedang di pihak lain didasarkan pada penguasaan fisik diatas tanah tersebut.

$$
\text { Sebagaimana dikemukakan }
$$
diatas, pelaksanaan pembebasan tanah untuk kepentingan umum memang hampir selalu mengalami hambatan dan tantangan. Sebetulnya dimana letak permasalahnnya, apakah terletak pada prosedur atau kultur.. Untuk mengubah kultur masyarakat dalam melepaskan haknya atas tanah perlu mencari persamaan kultur antara Pemerintah dan masyarakat, karena selama tidak ada persamaan kultur akan selalu mengalami permasalahan serius. Sebetulnya perbedaan kultur antara pemerintah dengan masyarakat terletak pada penetapan harga ganti rugi belaka.

Dibalik itu pemerintah dalam menentukan harga hanya berpatokan pada Nilai Jual Objek Pajak (NJOP) yang besarnya ditentukan oleh Kantor Pajak Bumi dan Bangunan. Dalam merencanakan ganti rugi tanah terhdap penduduk yang terkena pembebasan tanah, setidak-tidaknya harus:

1. Memperhatikan aspek-aspek fisik, misalnya ukuran tanah, kondisi 
Abuyazid Bustomi dan Barhamudin, Konsolidasi Sebagai Alternatif Penyediaan Tanah Untuk Pembangunan Sarana dan Fasilitas Umum, Halaman 46-63

arsitektur bangunan, konstruksi interior dan eksterior bangunan, ukuran bangunan, fasilitas yang ada pada bangunan, serta harapanharapan perkembangannya.

2. Memperhatikan aspek-aspek kondisi lingkungan, sosial dan fisik, dan kehidupan yang akan datang, mata pencaharian serta strata sosialnya (apakah termasuk golongan orang kaya atau tergolong miskin).

3. Memperhatikan data-data pasar harga tanah. ${ }^{2}$

Pembebasan tanah milik masyarakat oleh pemerintah sering terjadi disertai dengan penyelesaian yang tidak tuntas, bahkan di masa lalu menggunakan kekuatan tentara agar pengambilan tanah berhasil dilakukan tanpa proses ganti rugi kepada pemilik tanah. $^{3}$ Dalam pembebasan tanah lembaga penilai yang dimaksudkan disini adalah yang telah mendapat lisensi dari Pemerintah sebagai lembaga penilai yang netral, disamping itu memang lembaga ini telah mempunyai keahlian di bidangnya. Arti netral dari lembaga ini keberadaannya tidak ada sangkut paut dengan instansi pemerintah, sehingga tidak ada kemungkinan kerja sama instansi

2 Bambang Tri Cahyo, Ekonomi Pertanahan (Yogyakarta: Liberti, 1983).

3 Balya S, "Krisis Tanah di Daerah

Perkotaan," Prisma No. 1 Tahun XVI (2007): 94. pemerintah dalam menentukan harga ganti rugi tanah. Dibalik itu diharapkan juga tidak terjadi kerja sama dengan pemilik tanah yang terkena pembebasan. Kalau lembaga ini bertindak tidak netral tentu akan dikenakan sanksi oleh lembaga Pemerintah yang mengeluarkan izin operasional.

Apabila pihak pengembang menginginkan sebidang tanah, maka tanah tersebut dibeli dengan membentuk panitia pembelian tanah.Pemilihan lokasi tanah oleh pihak pengembang didasarkan pada pertimbangan bahwa lokasi tanah tersebut sangat cocok untuk pembangunan suatu fasilitas umum yang tidak terdapat pada lokasi tanah lain.Tanah yang ingin dibebaskan hendaknya terhindar dari maslahmasalah antara antara sesama pemilik dan antara pemilik tanah dengan keluarga atau kerabat misalnya penetapan batas pemilikan tanah atau sengketa tanah warisan. Apabila masalah-masalah tersebut belum diselesaikan, maka akan menghambat proses pembebasan tanah tersebut. Adapun yang menyelesaikan masalah tersebut adalah para pihak pemilik tanah dan keluarga atau kerabatnya. 
Abuyazid Bustomi dan Barhamudin, Konsolidasi Sebagai Alternatif Penyediaan Tanah Untuk Pembangunan Sarana dan Fasilitas Umum, Halaman 46-63

Pertama langkah awal dari proses pembebasan tanah adalah mengadakan pendekatan-pendekatan dengan memberikan penjelasan-penjelasan yang terinci mengenai tata cara pembebasan tanah, penggunaan tanah tersebut setelah dibebaskan, dan besarnya ganti rugi yang akan diberikan.

Kedua, adalah langkah pembuatan akta. Apabila masalahmasalah yang menghambat acara pembebasan tanah telah dapat diselesaikan, maka langkah kedua dari pembebasan tanah adalah membuat perjanjian atau persetujuan. Perjanjian atau persetujuan ini menandakan bahwa penduduk bersedia melepaskan tanahnya dan menerima ganti rugi yang telah disepakati bersama antara pemilik tanah dan pihak pengembang.Persetujuan ini ditandatangani oleh kepala desa sebagai wakil dari masyarakat dan pihak pengembang. Dam Ketiga, adalah proses ganti rugi. Langkah ketiga dalam acara pembebasan tanah adalah proses ganti rugi yang diberikan dari pihak pengembang.

Peraturan Presiden Nomor 65 Tahun 2006 tentang Pengadaan Tanah Bagi Pelaksanaan Pembangunan Untuk
Kepentingan Umum, dan cara perhitungan ganti kerugian ditetapkan atas dasar: ${ }^{4}$

1. NJOP nyata/sebenarnya dengan memperhatikan NJOP tahun berjalan berdasarkan penetapan lembaga/Tim penilai harga Tanah yang ditunjuk oleh panitia;

2. Nilai Jual bangunan yang ditaksir oleh Perangkat daerah yang bertanggung jawab di bidang bangunan;

3. Nilai jual tanaman yang ditaksir oleh Perangkat Daerah yang bertanggung jawab di bidang pertanian.

Sebagian besar pembangunan di segala bidang memerlukan tanah, baik sebagai tempat untuk membangun maupun sebagai faktor produksi, yang pengadaan dan pemanfaatannya dengan berwawasan lingkungan, antara lain dilaksanakan melalui penataan kembali penguasaan dan penggunaan tanah. Pada lokasi-lokasi tertentu penataan kembali tersebut akan efisien jika dilaksanakan melalui konsolidasi tanah, sebagai perwujudan keinginan membangun dari masyarakat, oleh masyarakat, dan untuk masyarakat.

Permasalahan dalam tulisan ini adalah bagaimanakah konsolidasi tanah sebagai alternatif penyediaan tanah untuk pembangunan sarana umum dan

\footnotetext{
4 Balya S
} 
Abuyazid Bustomi dan Barhamudin, Konsolidasi Sebagai Alternatif Penyediaan Tanah Untuk Pembangunan Sarana dan Fasilitas Umum, Halaman 46-63

fasilitas umum, serta apa saja hambatan-hambatan dalam pelaksanaan konsolidasi tanah sebagai alternatif penyediaan tanah untum pembangunan sarana umum dan fasilitas umum.

Penulis menggunakan metode penelitian normatif/kepustakaan, yaitu untuk mendapatkan data-data dari literatur-literatur, buku-buku dan peraturan perundang-undangan antara lain. Undang-Undang Nomor 5 Tahun 1960 tentang Pokok-Pokok Agraria, Undang-Undang Nomor 20 Tahun 1961 Tentang Pencabutan Hak-Hak Atas Tanah dan Pasal 15 Peraturan Presiden Nomor 65 Tahun 2006 Tentang Pengadaan Tanah Bagi Pelaksanaan Pembangunan Untuk Kepentingan Umum. Selanjutnya data yang didapat di analisa secara deduktif kualitatif, dengan menggunakan pendekatan secara yuridis normatif, yaitu dengan menganalisa dari nornanorma atau aturan-aturan yang berlaku.

\section{PEMBAHASAN}

\section{A. Pengertian dan Tujuan}

\section{Konsolidasi Tanah}

Konsolidasi Tanah merupakan salah satu model pembangunan dibidang pertanahan, yang mencakup wilayah perkotaan dan wilayah pertanian dan bertujuan mengoptimalkan penggunaan tanah dalam hubungan dengan pemanfaatan, peningkatan produktivitas dan konservasi bagi kelestarian lingkungan. ${ }^{5}$

Menurut AP. Parlindungan konsolidasi tanah dalah penggabungan dan atau pengaturan kembali tanahtanah sehingga akan sesuai dengan pembangunan yang direncanakan. Di daerah perkotaaan ataupun di pinggiran, yang karena satu dan lain hal akan berubah peruntukannya menjadi suatu daerah permukiman dan daerah pertanian. ${ }^{6}$

Dari definisi Pasal 1 butir 1 Peraturan Kepala Badan Pertanahan Nasional Nomor: 4 Tahun 1991 tentang Konsolidasi Tanah, terdapat dua kegiatan yang dilakukan sekaligus dalam Konsolidasi Tanah Perkotaan, yaitu:

a) Penataan kembali penguasaan dan penggunaan tanah; dan

b) Pengadaan Tanah untuk pembangunan.

5 Johara T. Jayadinata, Tata Guna Lahan dalam Perencanaan Pedesaan, Perkotaan dan Wilayah (Bandung: ITB Press, 1999).

6 A.P. Parlindungan, Bunga Rampai Hukum Agraria Serta Landreform Bagian I (Bandung: Mandar Maju, 1999). 
Abuyazid Bustomi dan Barhamudin, Konsolidasi Sebagai Alternatif Penyediaan Tanah Untuk Pembangunan Sarana dan Fasilitas Umum, Halaman 46-63

Makna penataan kembali berasal dari pemerintah, namun bisa menunjukkan bahwa kondisi faktual sebelum ditata dengan konsolidasi juga dari perusahaan swasta.

Secara umum, konsolidasi tanah tanah perkotaan, diatas tanah tersebut kenyataannya telah ada suatu bentuk penguasaan tanah yang tidak tertib dan penggunaan tanah yang tidak teratur. Dengan partisipasi dari masyarakat dalam hal ini para peserta konsolidasi tanah, maka ketidak tertiban penguasaan tanah dan ketidakteraturan penggunaan tanah ditata kembali, sekaligus diupayakan penyediaan tanah untuk kepentingan pembangunan prasarana jalan dan fasilitas umum lainnya. Konsolidasi tanah dapat dikatakan sebagai kebijakan pertanahan partisipatif dalam pemanfaatan tanah sebagaimana yang dialokasikan Rencana Tata Ruang untuk permukiman. ${ }^{7}$

Dewasa ini, konsolidasi tanah di Indonesia ditujukan kepada daerahdaerah kumuh ataupun kepada daerahdaerah perbatasan ataupun daerah pemukiman. Inisiatif untuk melaksanakan konsolidasi tanah

7 Oloan Sitorus, Keterbatasan Hukum Konsolidasi Tanah Perkotaan Sebagai Instrumen Kebijakan Pertanahan Partisipatif Dalam Penataan Ruang di Indonesia (Yogyakarta: Mitra Kebijakan Tanah Indonesia, 2006).

memiliki tujuan untuk mencapai kepastian hak atas tanah dan tanah secara optimal melalui perbaikan penguasaan tanah untuk mendukung pembangunan baik di perkotaan maupun di pedesaan.

Konsolidasi tanah dimaksudkan untuk mencapai pemanfaatan tanah secara optimal, melalui peningkatan efesien dan produktivitas penggunaan tanah serta peningkatan kualitas lingkungan. Konsolidasi tanah merupakan kebijaksanaan penataan kembali penguasaan dan penggunaan tanah serta usaha pengadaan tanah untuk kepentingan pembangunan dan meningkatkan kualitas lingkungan dan pemeliharaan sumber daya alam dengan melibatkan partisipasi aktif masyarakat, sehingga memerlukan pengaturan untuk mendorong dan memperlancar pelaksanaannya secara tertib.

Ketentuan Pasal 2 Peraturan kepala BPN Nomor 4 tahun 1991 tentang Konsolidasi tanah, menyatakan bahwa tujuan konsolidasi tanah adalah untuk mencapai pemanfaatan tanah secara optimal, melalui peningkatan 
Abuyazid Bustomi dan Barhamudin, Konsolidasi Sebagai Alternatif Penyediaan Tanah Untuk Pembangunan Sarana dan Fasilitas Umum, Halaman 46-63

efisiensi dan produktivitas penggunaan tanah, sedangkan sasaran konsolidasi tanah adalah terwujudnya suatu tatanan penguasaan dan penggunaan yang tertib dan teratur. Peningkatan yang demikian itu mengarah kepada tercapainya suatu tatanan pengunaan dan penguasaan yang tertib dan teratur.

Sedangkan sasaran konsolidasi tanah terutama ditujukan pada wilayah perkotaan meliputi:

a. permukiman kumuh;

b. wilayah permukiman yang tumbuh pesat;

c. wilayah permukiman yang mulai tumbuh;

d. wilayah yang direncanangkan menjadi permukiman baru;

e. wilayah yang relatif kosong di bagian pinggiran kota yang diperkirakan akan berkembang sebagai daerah permukiman.

Sedangkan wilayah pedesaan meliputi: ${ }^{8}$

a. wilayah yang potensial dapat memperoleh pengairan tetapi belum tersedia jaringan irigasi telah tersedia tetapi pemanfaatannya belum merata;

\footnotetext{
8 Philipus Hadjon, Pengantar Hukum Administrasi Indonesia (Yogyakarta: UGM press, 2007).
}

b. wilayah yang berpengairan cukup baik namun masih perlu ditunjang oleh pengadaan jaringan jalan yang memadai.

\section{B. Asas-Asas Konsolidasi Tanah}

Asas-Asas dalam pelaksanaan konsolidasi tanah perkotaan, adalah:

1. Asas Filosofi

Asas filosofi konsolidasi tanah adalah Pancasila, dalam hal ini adalah sila Keadilan Sosial Bagi Seluruh Rakyat Indonesia, yang dijiwai oleh sila-sila Pancasila lainnya. Dengan sila kelima Pancasila ini diharapkan bangsa Indonesia mampu mengembangkan perbuatan-perbuatan luhur yang mencerminkan sikap dan suasana kekeluargaan.

2. Asas Konstitusional

Asas

konstitusional penyelenggaraan konsolidasi tanah adalah Undang-Undang Dasar 1945 , khususnya Pasal 33 ayat (3) yang menyatakan bahwa bumi, air dan kekayaan alam yang terkandung di dalamnya dikuasai oleh Negara dan dipergunakan untuk sebesar-besarnya bagi kemakmuran rakyat. Penjelasan Pasal 33 Undang-Undang Dasar 1945 menyatakan bahwa bumi, air dan kekayaan alam yang terkandung dalam 
Abuyazid Bustomi dan Barhamudin, Konsolidasi Sebagai Alternatif Penyediaan Tanah Untuk Pembangunan Sarana dan Fasilitas Umum, Halaman 46-63

bumi adalah pokok-pokok

kemakmuran rakyat.

3. Asas Politis

Asas politis dalam penyelenggaraan konsolidasi tanah dapat dilihat dalam Garis-Garis Besar Haluan Negara (GBHN) beserta peraturan perundangundangan pelaksanaannya.

Selanjutnya konsolidasi tanah perkotaan sebagai kebijakan publik dibidang Pertanahan dalam memanfaatkan tanah sebagaimana yang dialokasikan rencana tata ruang kiranya harus tunduk pada asas-asas umum hukum mengenai penguasaan dan penatagunaan tanah serta asas-asas umum yang harus diperhatikan pada pemberian hak atas tanah sebagai salah satu bentuk penetapan pemerintah.

\section{Tinjauan Umum Tentang Hak- hak Penguasaan Atas Tanah}

\section{Hak Penguasaan Atas Tanah}

Istilah penguasaan dan menguasai dalam Kamus Besar Bahasa Indonesia adalah proses, cara, perbuatan menguasai atau mengusahakan. ${ }^{9}$ Pengertian penguasaan dan menguasai dapat dipakai dalam arti fisik juga

9 Poerwadarminta, W.J.S, Kamus Umum Bahasa Indonesia (Jakarta: Pusat Pembinaan dan Pengembangan Bahasa, Departemen Pendidikan dan Kebudayaan Republik Indonesia, 1991). dalam arti yuridis, juga beraspek perdata dan beraspek publik. ${ }^{10}$ Beraspek publik adalah hak penguasaan tertinggi yang dimiliki oleh negara yang meliputi semua tanah dalam wilayah negara, yang merupakan tanah bersama sebagaimana diatur dalam Pasal 33 ayat (3) UUD'45, bahwa bumi, air dan kekayaan alam yang terkandung didalamnya dikuasai oleh negara dan digunakan sebesarbesarnya bagi kemakmuran rakyat. Selanjutnya Pasal 2 ayat (1) UUPA menyebutkan, bahwa: Pengertian dikuasai bukan berarti dimiliki akan tetapi adalah negara sebagai yang diberi wewenang, selanjutnya dalam Pasal 2 ayat (2) UUPA menyebutkan, bahwa hak menguasai dari negara memberikan kewenangan untuk :

1. Mengatur dan menyelenggarakan peruntukan, penggunaan, persediaan dan pemeliharaan bumi, air dan ruang angkasa.

2. Menentukan dan mengatur hubungan hukum antara orangorang dengan bumi, air dan ruang angkasa.

10 Boedi Harsono, Hukum Agraria Indonesia; Sejarah Pembentukan Undang-Undang Pokok Agraria; Isi dan Pelaksanaannya (Jakarta: Djambatan, 2003). 
Abuyazid Bustomi dan Barhamudin, Konsolidasi Sebagai Alternatif Penyediaan Tanah Untuk Pembangunan Sarana dan Fasilitas Umum, Halaman 46-63

3. Menentukan dan mengatur hubungan-hubungan hukum antara orang-orang dan perbuatanperbuatan hukum yang mengenai bumi, air dan ruang angkasa.

Dalam Hukum Tanah Nasional diatur bermacam-macam hak penguasaan atas tanah yang disusun dalam jenjang tata susunan atau hirarki sebagai berikut:

1. Hak Bangsa, sebagai hak penguasaan atas tanah yang tertinggi, beraspek perdata dan publik.

2. Hak menguasai dari Negara, yang semata-mata beraspek publik, sebagaimana dinyatakan dalam Pasal 33 ayat (3) UUD 1945.

3. Hak Ulayat masyarakat Hukum Adat, beraspek perdata dan publik, diatur dalam Pasal 3 UndangUndang Pokok Agraria.

4. Hak-hak perorangan, yang semua beraspek perdata yang terdiri atas: $:^{11}$

a. Hak-hak atas tanah sebagai hakhak individual yang semua secara langsung atau tidak langsung bersumber pada hak bangsa yang disebut dalam Pasal 16 dan Pasal 53 UndangUndang Pokok Agraria. b. Wakaf, yaitu hak milik yang sudah diwakafkan, sebagaimana diatur dalam Pasal 49 UndangUndang Pokok Agraria.

c. Hak-hak jaminan atas tanah yang disebut Hak Tanggungan, sebagaimana diatur dalam Pasal 25, Pasal 33, Pasal 39 dan Pasal 51 Undang-Undang Pokok Agraria.

\section{Fungsi Sosial Atas Tanah}

Dalam Pasal 6 UUPA disebutkan: Semua hak atas tanah mempunyai sifat sosial. Konsepsi yang mendasari hukum tanah nasional adalah konsepsi hukum adat yang bersumber pada hak bersama bersumber pada masyarakat. Para warga diberi kemungkinan dan kesempatan untuk menguasai dan memiliki tanah itu, bukanlah untuk sekedar dipunyai, melainkan dengan tujuan untuk benar-benar dimanfaatkan. Sebagaimana halnya dalam konsepsi hukum adat, penguasaan tanah itu mengandung amanat untuk diusahakan dan dimanfaatkan. Membiarkan tanah tersebut dalam keadaan tidak diusahakan berarti menyalahi aturan, sebagaimana dinyatakan dalam Pasal 27, Pasal 34 dan Pasal 40 UUPA, yang intinya bahwa tanah tidak boleh ditelantarkan.

\footnotetext{
${ }^{11}$ Boedi Harsono
} 
Abuyazid Bustomi dan Barhamudin, Konsolidasi Sebagai Alternatif Penyediaan Tanah Untuk Pembangunan Sarana dan Fasilitas Umum, Halaman 46-63

Tanah yang dimiliki seseorang bukan hanya mempunyai fungsi bagi yang mempunyai hak itu saja, tetapi juga bagi bangsa Indonesia seluruhnya, sebagai konsekuensinya dalam mempergunakan tanah bukan hanya kepentingan yang berhak saja yang dipakai sebagai pedoman, tetapi juga harus diingat dan diperhatikan kepentingan masyarakat, harus diusahakan adanya keseimbangan antara kepentingan individu dalam hal ini pemilik dan kepentingan masyarakat. Untuk itu diperlukan adanya perencanaan peruntukan dan penggunaan tanah sebagaimana yang dimaksudkan dalam Pasal 14 UUPA. Fungsi sosial pada tanah mewajibkan kepada yang mempunyai hak untuk mempergunakan tanahnya sesuai dengan keadaan tanah yang bersangkutan, sehingga bermanfaat baik bagi kesejahteraan dan kebahagiaan yang mempunyai tanah maupun bermanfaat bagi masyarakat dan negara.

\section{Hak-Hak Atas Tanah}

Berdasarkan hak menguasai negara pasal 33 ayat (3), UUD 1945 semua tanah yang ada dalam wilayah Republik Indonesia dikuasai oleh negara, dan negara dapat menetapkan bidang-bidang tanah tersebut untuk dipunyai dan dimiliki oleh warga negaranya dengan sesuatu hak.

Tanah diberikan kepada orang dengan hak-hak yang telah disediakan oleh UUPA, adalah untuk digunakan atau dimanfaatkan. Namun, jika penggunaannya hanya terbatas pada tanah sebagai permukaan bumi saja. Untuk itu pasti diperlukan juga penggunaan sebagian tubuh bumi dan air serta ruang yang ada di atasnya untuk keperluan apapun. Oleh karena itu, dalam Pas al 4 ayat (2) UUPA dinyatakan, bahwa hak-hak atas tanah bukan hanya memberikan kewenangan untuk mempergunakan sebagian tertentu permukaan bumi yang bersangkutan, yang disebut "tanah", tetapi juga tubuh bumi dan air serta ruang yang ada di atasnya.

Dengan demikian maka yang dipunyai dengan hak atas tanah itu adalah tanahnya dalam arti sebagian tertentu dari permukaan bumi. Tetapi wewenang menggunakan yang bersumber pada hak tersebut diperluas hingga meliputi juga penggunaan sebagian tubuh bumi yang ada di bawah tanah, dan air 
Abuyazid Bustomi dan Barhamudin, Konsolidasi Sebagai Alternatif Penyediaan Tanah Untuk Pembangunan Sarana dan Fasilitas Umum, Halaman 46-63

serta ruang yang ada diatasnya.

Dengan demikian, hak atas tanah ialah hak yang memberi wewenang kepada yang mempunyai hak untuk mempergunakan dan mengambil manfaat dari tanah yang dihakinya.

Pemberian hak oleh negara kepada warga negaranya ditetapkan dalam suatu penetapan Pemerintah (beschikking), sekaligus suatu bukti hukum bagi rakyat bahwa yang bersangkutan adalah pemilik tanah, karenanya berhak mendapat perlindungan. Pemberian hak oleh negara kepada rakyatnya ini tidak bersifat ketatausahaan, melainkan peraturan hukum administrasi yang bersifat konstituitif.

\section{Konsolidasi Sebagai Alternatif Penyediaan Tanah Untuk Pembangunan Sarana Umum Dan Fasilitas Umum}

\section{Konsolidasi Tanah Sebagai} Metode Pengadaan Tanah Untuk Pembangunan Yang Partisipasif

Secara normatif, konsolidasi tanah baru diatur pada Peraturan Kepala BPN No. 4 Tahun 1991 tentang Konsolidasi tanah, yaitu: kebijaksanaan pertanahan mengenai penataan kembali penguasaan dan penggunaan tanah serta usaha pengadaan tanah untuk kepentingan pembangunan, untuk meningkatkan kualitas lingkungan dan pemeliharaan sumber daya alam dengan melibatkan partisipasi aktif masyarakat.

Konsolidasi tanah dianggap penting pada kebijakan pembangunan perumahan disebabkan konsolidasi tanah mempunyai ciri-ciri kekhasan sebagai berikut: ${ }^{12}$

a. Prosedur pelaksanaannya menghormati hak atas tanah dan menjunjung tinggi aspek keadilan dengan melibatkan partisipasi aktif para pemilik tanah melalui musyawarah dalam setiap pengambilan keputusan, baik dalam tahap perencanaan maupun dalam tahap pelaksanaannya;

b. Pemilik tanah diupayakan tidak tergusur dari lingkungannya;

c. Keuntungan yang diperoleh dari hasil peningkatan nilai tambah tanah dan biaya pelaksanaannya didistribusikan secara adil diantara pemilik tanah atau peserta konsolidasi;

d. Penataan penguasaan tanah dilakukan sekaligus dengan penataan penggunaan tanahnya serta pensertifikatan tanah yang telah dikonsolidasi;

12 Nad Darga Talkurputra, "Kebijaksanaan Pembangunan Pertanahan dan Peranan Konsolidasi Tanah," Makalah pada Lokakarya Konsolidasi Tanah Perkotaan, Bandung (1997): 9. 
Abuyazid Bustomi dan Barhamudin, Konsolidasi Sebagai Alternatif Penyediaan Tanah Untuk Pembangunan Sarana dan Fasilitas Umum, Halaman 46-63

e. Biaya pelaksanaan diupayakan dari pemilik tanah sehingga tidak hanya mengandalkan biaya dari pemerintah yang sangat terbatas;

f. Penggunaan tanah ditata secara efisien dan optimal dengan mengacu kepada Rencana Tata Ruang Wilayah/Rencana Pembangunan Wilayah, sekaligus menyediakan tanah untuk sarana dan prasarana yang dibutuhkan sehingga dapat mendukung kebijakan pemerintah daerah.

Asas keikutsertaan/partisipasif merupakan dukungan dalam penyelenggaraan pengadaan tanah yakni melalui partisipasi masyarakat baik secara langsung mapun secara tidak langsung sejak perencanaan sampai dengan kegiatan pembangunan. Partisipasi masyarakat mempunyai peran penting dalam terwujudnya pengadaan tanah melalui metode konsolidasi. Jika dari aspek penataan ruang partisipasi masyarakat diwujudkan dalam peran masyarakat dalam proses penataan ruang, yang dituangkan dalam bentuk hukum PP No. No. 68 Tahun 2010 tentang Bentuk dan Tata Cara Peran Masyarakat dalam Penataan Ruang, maka dari perspektif hukum konsolidasi tanah pun harus diatur paling rendah dalam bentuk hukum peraturan pemerintah, sehingga konsolidasi tanah sebagai wujud peran masyarakat mempunyai dasar hukum yang cukup kuat.

\section{Konsolidasi Tanah Sebagai Alternatif Penyediaan Tanah Untuk Pembangunan Sarana}

\section{Umum Dan Fasilitas Umum}

Untuk mendukung pelaksanaan tata ruang perkotaan maka dibutuhkan suatu konsep pengaturan pertanahan yang mampu meminimalisasi dampak di atas. Konsep yang dapat memadukan aspek legalitas penguasaan tanah dan aspek fisik pengunaan tanah ini disebut dengan konsolidasi tanah. Penerapan konsolidasi tanah ini berkaitan erat dengan struktur penguasaan/pemilikan tanah dan rencana pembangunan yang digariskan oleh pemerintah.

Konsolidasi tanah dapat diartikan sebagai salah satu dari kebijakan pertanahan mengenai penataan penguasaan dan pengunaan tanah berdasarkan rencana Tata Ruang Kota yang dalam proses pembangunannya akan dilengkapi dengan perencanaan prasarana, sarana, fasilitas dan utilitas umum yang diperlukan sesuai potensi lokasi yang bersangkutan, melalui peran serta aktif para pemilik tanah atau penggarap tanah untuk menunjang 
Abuyazid Bustomi dan Barhamudin, Konsolidasi Sebagai Alternatif Penyediaan Tanah Untuk Pembangunan Sarana dan Fasilitas Umum, Halaman 46-63

perwujudan rencana pembangunan daerah yang bersangkutan. $^{13}$ Konsolidasi tanah juga merupakan kebijaksanaan pertanahan untuk menata kembali penguasaan, pemilikan, dan penggunaan tanah sesuai dengan rencana tata ruang kota berdasarkan peraturan perundangundangan yang berlaku.

Konsep Konsolidasi Tanah menurut Peraturan Kepala Badan Pertanahan Nasional Nomor 4 tahun 1991 tentang Konsolidasi tanah, sasaran pengaturannya adalah pada bidang-bidang tanah yang ditata kembali, mengenai bentuk, luas dan letaknya sehingga nilai tanah meningkat. Dalam hal ini, pemilik tanah menyerahkan tanahnya kepada Pemerintah untuk ditata kembali dan ada sebagian yang diperlukan untuk pembangunan sarana umum dan sebagian yang dipergunakan untuk Tanah Pengganti Biaya Pelaksanaan (TPBP). Asas yang dipakai dalam pelaksanaan konsolidasi tanah ini adalah musyawarah.

Konsolidasi tanah merupakan salah satu instrumen yang baik untuk mendukung perencanaan suatu

13 Bambang Santoso et.al, Paradigma baru Pengelolaan Pertanahan Pada Era Otonomi Daerah (Jakarta, 2005). kawasan perkotaan. Pengaturan terhadap bentuk, luas, dan letak tanah memberikan dampak yang positif terhadap pembangunan perkotaan. Dengan melakukan konsolidasi tanah di daerah perkembangan kota maka perluasan ke daerah pinggiran dapat dikendalikan. Disamping itu pembangunan di kawasan perkotaan dapat berjalan lebih terencana. Inilah yang menyebabkan betapa pentingnya konsolidasi tanah dalam penataan ruang kawasan perkotaan. Oleh karena itu, hendaknya Pemerintah Daerah juga memberikan perhatian terhadap penelitian dan pengembangan konsolidasi tanah.

Pemberian jaminan kepastian hak atas tanah kepada masyarakat merupakan salah satu motivasi masyarakat untuk ambil bagian dalam pelaksanaan konsolidasi tanah. Bersamaan dengan upaya penerapan konsolidasi tanah, maka juga perlu dilakukan penetapan nilai tanah yang terpadu yang baku dan konsisten. Artinya ada harga yang dapat mendekatkan para pihak, yakni pihak pemerintah dan pihak yang terkena pembebasan tanah. ${ }^{14}$

\footnotetext{
${ }^{14}$ Bambang Santoso
} 
Abuyazid Bustomi dan Barhamudin, Konsolidasi Sebagai Alternatif Penyediaan Tanah Untuk Pembangunan Sarana dan Fasilitas Umum, Halaman 46-63

E. Hambatan-Hambatan Donsolidasi tanah berkaitan dengan

Pelaksanaan Konsolidasi Tanah

Sebagai Alternatif Penyediaan

Tanah Untum Pembangunan

Sarana Umum dan Fasilitas

Umum

Salah satu instrumen yuridis yang digunakan Badan Pertanahan Nasional Republik Indonesia dalam konsolidasi tanah adalah menggunakan instrumen hukum publik berupa Keputusan Bupati/Walikota. Hal tersebut karena konsolidasi tanah berkaitan dengan rencana tata ruang, wewenang mengatur rencana tata ruang bukan wewenang Badan Pertanahan Nasional Republik Indonesia. Peraturan Daerah tentang Rencana Tata Ruang adalah wewenang daerah dimana Bupati/Walikota dalam kedudukan sebagai Kepala Daerah.

Konsolidasi tanah tidak bisa dilaksanakan apabila tidak sesuai dengan rencana tata ruang. Permasalahannya, untuk mewujudkan suatu rencana tata ruang di kawasan yang ditetapkan adalah adanya hak-hak atas tanah perorangan atau badan hukum perdata. Disini terlihat ada batas kewenangan antara Badan Pertanahan Nasional Republik Indonesia dan Bupati/Walikota dalam rencana tata ruang.

Pembebasan tanah untuk rencana tata ruang yang lazimnya ditempuh oleh badan atau pejabat tata usaha negara adalah melalui pengadaan tanah yang berarti memindahkan mereka dengan suatu rencana peruntukan kepentingan umum. Penetapan tersebut akan mengakibatkan terjadi pencabutan atau pembatasan hak atas tanah yang mengakibatkan seseorang atau badan hukum perdata kehilangan hak atas tanahnya sendiri. Dikeluarkannya instrumen hukum publik berupa Keputusan Bupati/Walikota tentang Penetapan Lokasi Konsolidasi Tanah, menimbulkan pertanyaan apa hambatan hambatan yang terjadi dalam rangka konsolidasi tanah sebagai alternatif penyediaan tanaag untuk pembangunan sarana umum dan fasilitas umum. Hambatan-hambatan dimaksud adalah sebagai berikut:

\section{Hambatan dari Pemilik Tanah}

Sebelum lokasi konsolidasi tanah ditetapkan dengan Surat Keputusan Bupati/Walikota, salah satu persyaratan penetapan obyek konsolidasi tanah adalah adanya kesediaan pemilik tanah untuk menyetujui pelaksanaan konsolidasi tanah. Dengan kata lain 
Abuyazid Bustomi dan Barhamudin, Konsolidasi Sebagai Alternatif Penyediaan Tanah Untuk Pembangunan Sarana dan Fasilitas Umum, Halaman 46-63

menyetujui melepaskan sebagian hak atas tanahnya untuk disumbangkan dalam konsolidasi tanah tanpa ganti rugi berupa uang.

Makna "menyetujui" adalah sepakat. Kesepakatan melahirkan perjanjian. Perjanjian menimbulkan perikatan, dan perikatan menimbulkan akibat hukum. Akibat hukum diatur dalam hukum perjanjian. Dengan kata lain perjanjian digunakan dalam konsolidasi tanah. Untuk mencapai hal tersebut, langkah yang ditempuh Kantor Pertanahan Kabupaten/kota sebagai pelaksana konsolidasi tanah adalah melakukan penyuluhan untuk mendapatkan persetujuan dari pemilik tanah.

Penyuluhan dilaksanakan Kantor Pertanahan dan Pemerintah Daerah secara langsung. Penyuluhan diberikan kepada masyarakat terutama para pemilik tanah di lokasi kosolidasi tanah, pemuka masyarakat, pemuka adat (pemimpin informal), Ketua RW dan aparat pelaksana pada lokasi terpilih. Hal tersebut dimaksudkan agar masyarakat semakin mengerti tentang manfaat kegiatan konsolidasi tanah dan ikut secara aktif dalam pelaksanaannya.

Penyuluhan kepada aparat pelaksana dimaksudkan agar aparat mengerti tugas dan tanggung jawab dalam melaksanakan kegiatan konsolidasi tanah. Adapun materi penyuluhannya yaitu:

a) kegiatan konsolidasi tanah secara umum;

b) manfaat konsolidasi tanah bagi peserta;

c) sumbangan peserta dalam konsolidasi tanah berupa Sumbangan Tanah Untuk Pelaksanaan (STUP);

d) susunan organisasi pelaksana konsolidasi tanah;

e) dan lain-lain yang berkaitan dengan pelaksanaan konsolidasi tanah.

Perjanjian diatur dalam Pasal 1338 BW: Semua perjanjian yang dibuat secara sah berlaku sebagai undangundang bagi mereka yang membuatnya. Persetujuan-persetujuan itu tidak dapat ditarik kembali selain dengan sepakat kedua belah pihak atau karena alasan-alasan yang oleh undang-undang dinyatakan cukup untuk itu. Persetujuan-persetujuan harus dilaksanakan dengan itikad baik.

Merujuk Pasal 1338 BW, menurut hukum perdata tanpa persetujuan pemilik tanah untuk melepaskan hak atas tanahnya Badan Pertanahan 
Abuyazid Bustomi dan Barhamudin, Konsolidasi Sebagai Alternatif Penyediaan Tanah Untuk Pembangunan Sarana dan Fasilitas Umum, Halaman 46-63

Nasional Republik Indonesia yang mempunyai kewenangan di bidang pertanahan sekalipun tidak bisa menggunakan kewenangannya untuk melaksanakan konsolidasi tanah. Di sisi lain, Bupati/Walikota tidak mempunyai wewenang mengatur di bidang pertanahan, hanya berwenang menetapkan lokasi konsolidasi tanah.

Bupati/Walikota bisa menetapkan lokasi konsolidasi tanah tetapi tidak bisa melaksanakan keputusan tersebut apabila tidak ada persetujuan dari pemilik tanah (lihat Pasal 4 ayat (2) di atas). Dengan demikian, peran serta (inspraak) atau persetujuan pemilik tanah dalam konsolidasi tanah menentukan. Dengan kata lain, tanpa adanya kesepakatan dari pemilik pemilik tanah Keputusan Bupati/Walikota yang dikeluarkan tidak bisa dilaksanakan. ${ }^{15}$

\section{Masalah dari Pemerintah}

\section{Daerah}

Penataan ruang diatur dalam Undang-Undang Nomor 24 Tahun 1992 tentang Penataan Ruang yang diganti dengan Undang Undang Nomor 26 Tahun 2007. Rencana Tata Ruang Wilayah Kabupaten/Kota dan atau

\footnotetext{
${ }^{15}$ Ilhami, Strategi Pembangunan Perkotaan di Indonesia (Surabaya: Usaha Nasional, Surabaya, 1990).
}

Rencana Detail Tata Ruang Kota (RDTRK) dan Rencana Teknik Ruang Kota (RTRK) menjadi pedoman untuk perumusan kebijaksanaan pokok pemanfaatan ruang dan penetapan lokasi investasi di wilayah Kabupaten/Kota serta menjadi dasar bagi penerbitan perizinan lokasi pembangunan.

Masalah dari pemerintah daerah dalam konsolidasi tanah adalah wewenang yang terbatas karena pembatasan hak atas tanah bukan wewenang Bupati/Walikota. Percampuran antara wewenang Bupati/Walikota dalam rencana tata ruang dan dalam menetapkan lokasi konsolidasi tanah dengan tugas Bupati/Walikota sebagai tim koordinasi dalam konsolidasi tanah. Sehingga ada percampuran antara kewenangan dan ketidakwenangan Bupati/Walikota dalam konsolidasi tanah. Penggunaan Peraturan Kepala Badan Pertanahan Nasional Nomor 4 Tahun 1991 dalam konsolidasi tanah membuka peluang yang besar terjadinya gugatan dari pemilik tanah atau badan hukum perdata. 
Abuyazid Bustomi dan Barhamudin, Konsolidasi Sebagai Alternatif Penyediaan Tanah Untuk Pembangunan Sarana dan Fasilitas Umum, Halaman 46-63

KESIMPULAN DAN

\section{REKOMENDASI}

Konsolidasi tanah dapat diartikan sebagai penguatan nilai dan fungsi tanah sebagai hasil penataan bentuk, luas, dan letak sehingga menjadi tertib dan teratur yang mendukung pemanfaatan lahan secara efektif dan efisien sesuai potensinya. Adapun hambatannya apabila ada masyarakat yang keberatan dengan konsolidasi tanah untuk pembangunan kepentingan umum dan fasilitas umum, yakni masalah dari pemilik tanah dalam konsolidasi tanah, hambatan dalam mendapatkan persetujuan atau kesepakatan dari pemilik tanah dalam konsolidasi tanah karena persetujuan pemilik tanah menentukan dikeluarkannya keputusan Bupati/Walikota tentang penetapan lokasi konsolidasi tanah. Hambatan dari pemerintah daerah dalam konsolidasi tanah adalah wewenang yang terbatas karena pembatasan hak atas tanah bukan wewenang Bupati/Walikota.

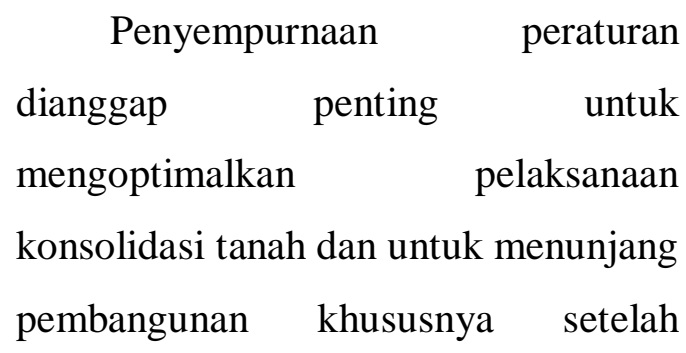

pemberlakuan otonomi daerah. Sehingga kebijakan dapat dijadikan sebagai pedoman pelaksanaan konsolidasi tanah di perkotaan sesuai rencana tata ruangnya.

\section{DAFTAR PUSAKA}

Balya S, "Krisis Tanah di Daerah Perkotaan," Prisma No. 1 Tahun XVI (2007): 94.

Cahyo, Bambang Tri. Ekonomi Pertanahan. Yogyakarta: Liberti, 1983.

Hadjon, Philipus. Pengantar Hukum Administrasi Indonesia. Yogyakarta: UGM press, 2007.

Harsono, Boedi. Hukum Agraria Indonesia; Sejarah Pembentukan Undang-Undang Pokok Agraria; Isi dan Pelaksanaannya. Jakarta: Djambatan, 2003.

Ilhami, Strategi Pembangunan Perkotaan di Indonesia. Surabaya: Usaha Nasional, Surabaya, 1990.

Jayadinata, Johara T. Tata Guna Lahan dalam Perencanaan Pedesaan, Perkotaan dan Wilayah. Bandung: ITB Press, 1999.

Mukadir, "Model Pembebasan Tanah Untuk Kepentingan Umum," Jurnal Media Jaya No. 006 Th XXVIII Juli (2004): 48.

Parlindungan, A.P. Bunga Rampai Hukum Agraria Serta Landreform Bagian I. Bandung: Mandar Maju, 1999.

Poerwadarminta, W.J.S, Kamus Umum Bahasa Indonesia. Jakarta: Pusat 
Abuyazid Bustomi dan Barhamudin, Konsolidasi Sebagai Alternatif Penyediaan Tanah Untuk Pembangunan Sarana dan Fasilitas Umum, Halaman 46-63

Pembinaan dan Pengembangan Bahasa, Departemen Pendidikan dan Kebudayaan Republik Indonesia, 1991.

Santoso, Bambang et.al, Paradigma baru Pengelolaan Pertanahan Pada Era Otonomi Daerah. Jakarta, 2005.

Sitorus, Oloan. Keterbatasan Hukum Konsolidasi Tanah Perkotaan Sebagai Instrumen Kebijakan
Pertanahan Partisipatif Dalam Penataan Ruang di Indonesia. Yogyakarta: Mitra Kebijakan Tanah Indonesia, 2006.

Talkurputra, Nad Darga. "Kebijaksanaan Pembangunan Pertanahan dan Peranan Konsolidasi Tanah," Makalah pada Lokakarya Konsolidasi Tanah Perkotaan, Bandung (1997): 9. 